Letter

Subscriber access provided by UNIVERSITY OF TECHNOLOGY SYDNEY

\title{
Highly Doped Upconversion Nanoparticles for In Vivo Applications Under Mild Excitation Power
}

Du Li, Shihui Wen, Mengya Kong, Yongtao Liu, Wei Hu, Bingyang Shi, Xiangyang Shi, and Dayong Jin Anal. Chem., Just Accepted Manuscript • DOI: 10.1021/acs.analchem.0c02143 • Publication Date (Web): 29 Jul 2020

Downloaded from pubs.acs.org on August 4, 2020

\section{Just Accepted}

"Just Accepted" manuscripts have been peer-reviewed and accepted for publication. They are posted online prior to technical editing, formatting for publication and author proofing. The American Chemical Society provides "Just Accepted" as a service to the research community to expedite the dissemination of scientific material as soon as possible after acceptance. "Just Accepted" manuscripts appear in full in PDF format accompanied by an HTML abstract. "Just Accepted" manuscripts have been fully peer reviewed, but should not be considered the official version of record. They are citable by the Digital Object Identifier (DOI®). "Just Accepted" is an optional service offered to authors. Therefore, the "Just Accepted" Web site may not include all articles that will be published in the journal. After a manuscript is technically edited and formatted, it will be removed from the "Just Accepted" Web site and published as an ASAP article. Note that technical editing may introduce minor changes to the manuscript text and/or graphics which could affect content, and all legal disclaimers and ethical guidelines that apply to the journal pertain. ACS cannot be held responsible for errors or consequences arising from the use of information contained in these "Just Accepted" manuscripts. 


\title{
Highly Doped Upconversion Nanoparticles for In Vivo Applications Under Mild Excitation Power
}

\author{
Du Li ${ }^{1,2}$, Shihui Wen ${ }^{1 *}$, Mengya Kong ${ }^{3}$, Yongtao Liu ${ }^{1}$, Wei Hu${ }^{2}$, Bingyang Shi ${ }^{4}$, Xiangyang Shi2* and \\ Dayong Jin ${ }^{1,5^{*}}$
}
${ }^{1}$ Institute for Biomedical Materials and Devices (IBMD), Faculty of Science, University of Technology Sydney, NSW 2007, Australia
${ }^{2}$ College of Chemistry, Chemical Engineering and Biotechnology, Donghua University, Shanghai 201620, People's Republic of China
${ }^{3}$ Department of Chemistry \& Institutes of Biomedical Sciences \& State Key Laboratory of Molecular Engineering of Polymers, Fudan University, Shanghai, China.
${ }^{4}$ Department of Biomedical Sciences, Faculty of Medicine \& Health Sciences, Macquarie University, Sydney, New South Wales 2109, Australia

5UTS-SUStech Joint Research Centre for Biomedical Materials \& Devices, Department of
Biomedical Engineering, Southern University of Science and Technology, Shenzhen, China

E-mail: shihui.wen@uts.edu.au (S. Wen),xshi@dhu.edu.cn (X. Shi) and dayong.jin@uts.edu.au (D. Jin) 
One of the major challenges in using upconversion nanoparticles (UCNPs) is to improve their brightness. This is particularly true for in vivo studies, as the low power excitation is required to prevent the potential photo toxicity to live cells and tissues. Here, we report that the typical $\mathrm{NaYF}_{4}: \mathrm{Yb}_{0.2}, \mathrm{Er}_{0.02}$ nanoparticles can be highly doped, and the formula of $\mathrm{NaYF}_{4}: \mathrm{Yb}_{0.8}, \mathrm{Er}_{0.06} \mathrm{can}$ gain orders of magnitude more brightness, which is applicable to a range of mild $980 \mathrm{~nm}$ excitation power densities, from $0.005 \mathrm{~W} / \mathrm{cm}^{2}$ to $0.5 \mathrm{~W} / \mathrm{cm}^{2}$. Our results reveal that the concentration of $\mathrm{Yb}^{3+}$ sensitizer ions plays an essential role, while increasing the doping concentration of $\mathrm{Er}^{3+}$ activator ions to $6 \mathrm{~mol} \%$ only has incremental effect. We further demonstrated a type of bright UCNPs $12 \mathrm{~nm}$ in total diameter for in vivo tumor imaging at a power density as low as $0.0027 \mathrm{~W} / \mathrm{cm}^{2}$, bringing down the excitation power requirement by 42 times. This work re-defines the doping concentrations to fight for the issue of concentration quenching, so that ultra-small and bright nanoparticles can be used to further improve the performance of upconversion nanotechnology in photodynamic therapy, light-triggered drug release, optogenetics, and night vision enhancement.

Upconversion materials can absorb two or more near-infrared (NIR) photons and emit shorter wavelength luminescence in the visible and ultraviolet (UV) ${ }^{1-3}$. Such a fascinating anti-Stokes property has led to a broad range of optoelectronics applications, including full-colour displays ${ }^{4}$, security inks ${ }^{5}$, photocatalysis ${ }^{6}$, and photovoltaics ${ }^{7}$. By taking the advantage of NIR deep penetration through the tissue as well as their exceptional photo stability, long decaying lifetimes ${ }^{8}$, large anti-stoke shifts and sharp emission spectra, the emerging field of lanthanide doped upconversion nanoparticles (UCNPs) has attracted a great deal of interests in bio-imaging ${ }^{9-12}$, light-controlled nanomedicine ${ }^{3,13-16}$ and NIR night vision enhancement ${ }^{17}$.

One of the major challenges to transform upconversion nanotechnology is to reduce the excitation power requirement and improve the brightness of UCNPs. Due to the constraint of concentration quenching, the dopant concentrations are restricted at relatively low levels, e.g. $20 \mathrm{~mol}^{\circ} \mathrm{Yb}^{3+}$ as sensitizers and $2 \mathrm{~mol} \% \mathrm{Er}^{3+}$ or $0.5 \mathrm{~mol}^{2} \mathrm{Tm}^{3+}$ as activators ${ }^{18,19}$, to minimize luminescence quenching effects. In 2013, we reported that highly $\mathrm{Tm}^{3+}$-doped UCNPs can display exceptionally high brightness, 
where high excitation power (up to $\sim 10^{6} \mathrm{~W} / \mathrm{cm}^{2}$ ) was necessary to mitigate concentration quenching 20. Significant efforts have been made to improve the brightness of UCNPs by increasing the doping concentrations of sensitizers and activators ${ }^{21-23}$. Remarkably, Steven Chu's group recently reported that highly $\mathrm{Yb}^{3+}$ and $\mathrm{Er}^{3+}$ doped nanocrystals exhibit a 150 -fold enhancement at $8 \mathrm{~W} / \mathrm{cm}^{2}$ using an inert shell strategy ${ }^{22}$, and in parallel, the team led by Cohen, Chan, and Schuck at Berkeley reported that alloyed UCNPs can realize a deep-tissue imaging under the excitation power of $0.1 \mathrm{~W} / \mathrm{cm}^{2}{ }^{21}$.

Low-power excitation is required for the safe in vivo applications, e.g. the power densities in the range of 0.001 to $0.5 \mathrm{~W} / \mathrm{cm}^{2}$ are needed for bioimaging ${ }^{10}$, NIR-triggered drug release ${ }^{3}$, photodynamic therapy ${ }^{14,24}$, and night vision enhancement ${ }^{17}$. This gap between the high brightness and low power excitation becomes more evident when the size of UCNPs is within $15 \mathrm{~nm}$, where the number of dopants per nanoparticles proportionally drops and surface quenching inevitably arises 25,26 .

Here, we find that the concentrations of both $\mathrm{Yb}^{3+}$ sensitizers and $\mathrm{Er}^{3+}$ activators can be further fine-tuned and gain the significant enhancement in the brightness of UCNPs for in vivo applications when only mild to ultra-low irradiance are required. We adopt here a series of controlled synthesis of core@shell@shell UCNPs $\left(\mathrm{NaYF}_{4} @ \mathrm{NaYF}_{4}: \mathrm{Yb}_{\mathrm{x}}, \mathrm{Er}_{\mathrm{y}} @ \mathrm{NaYF}_{4}\right)$ to exclude the size effect, so that the influences of sensitizers' and activators' concentrations on the brightness of multi-colour upconversion emission can be systematically compared and quantified at a range of laser irradiance. For example, under an irradiance of $0.082 \mathrm{~W} / \mathrm{cm}^{2}$, compared with the widely-used $\mathrm{NaYF}_{4}: \mathrm{Yb}_{0.2}, \mathrm{Er}_{0.02}$ ones, the new formula of $\mathrm{NaYF}_{4}: \mathrm{Yb}_{0.8}, \mathrm{Er}_{0.06}$, yields the luminescence enhancements of 75.3, 40.8, 10.0, and 37.0 folds in ultraviolet, violet, green, and red emissions, respectively. This has further guided us to achieve a new type of $12 \mathrm{~nm}$ highly-doped core-shell UCNPs with much enhanced red emissions for in vivo imaging using an excitation irradiance as low as $0.0027 \mathrm{~W} / \mathrm{cm}^{2}$.

To quantify the roles of the concentrations of sensitizer ions and activator ions in enhancing the brightness of UCNPs, it requires the size of single UCNPs should be identical. Due to the difference in crystalline unit cells, the changes of $\mathrm{Yb}^{3+}$ concentrations, particularly at high levels, can significantly affect the overall size of nanoparticles when they are synthesized by the conventional coprecipitation method ${ }^{23}$. Therefore, we use an inert $\mathrm{NaYF}_{4}$ core as the template and design a heterogeneous sandwich structure of inert-core@active-shell@inert-shell nanoparticles (Fig. 1a-c), so that the $\mathrm{Yb}^{3+}$ and $\mathrm{Er}^{3+}$ 
concentrations can be arbitrarily tuned within the same volume of the active shell in the middle. The role of the inert $\mathrm{NaYF}_{4}$ shell is to minimize non-radiative energy loss by preventing the exciton energy transfer to the surface defects and surrounding solvents via $\mathrm{Yb}^{3+}$ ions.

As shown in Fig. 1b-c, transmission electronic microscopy (TEM) images show the typical batches of highly uniform nanocrystals of $\mathrm{NaYF}_{4}, \quad \mathrm{NaYF}_{4} @ \mathrm{NaYF}_{4}: \mathrm{Yb}_{0.2}, \mathrm{Er}_{0.02}, \quad$ and $\mathrm{NaYF}_{4} @ \mathrm{NaYF}_{4}: \mathrm{Yb}_{0.2}, \mathrm{Er}_{0.02} @ \mathrm{NaYF}_{4}$, synthesized by the layer-by-layer hot injection method ${ }^{27}$. The sizes of core, core@shell, and core@shell@shell nanoparticles are 18 nm, 28 nm and 34 nm, respectively, indicating $5 \mathrm{~nm}$ active shell and $3 \mathrm{~nm}$ inert shell (Fig. S1). With the increase doping concentration of bother $\mathrm{Yb}^{3+}(80 \%)$ and $\mathrm{Er}^{3+}(6 \%)$ in the active shell, we get the highly doped core@shell@shell nanoparticles with the similar size (Fig. 1b-c). The actual concentrations of $\mathrm{Y}^{3+}$, $\mathrm{Yb}^{3+}$ and $\mathrm{Er}^{3+}$ of core@shell@shell nanoparticles are further characterized by using inductively coupled plasma mass spectrometry. The molar ratios of $\mathrm{Y} / \mathrm{Yb} / \mathrm{Er}$ in active shell of $\mathrm{NaYF}_{4} @ \mathrm{NaYF}_{4}: \mathrm{Yb}_{0.2}, \mathrm{Er}_{0.02} @ \mathrm{NaYF}_{4}$ and $\mathrm{NaYF}_{4} @ \mathrm{NaYF}_{4}: \mathrm{Yb}_{0.8}, \mathrm{Er}_{0.06} @ \mathrm{NaYF}_{4}$ have been calculated to be $0.79: 0.19: 0.018$ and $0.15: 0.78: 0.063$, respectively, which confirms that rare earth compositions of UCNP consistent to their feeding ratio. Also, all the synthesized nanoparticles are uniform with narrow size distributions (Fig. S1), which supports the following quantitative comparisons of the upconversion luminescence intensities. As shown in Fig. 1d, the luminescence spectra of assynthesized UCNPs have four characteristic peaks at $379 \mathrm{~nm}$ (ultraviolet), $407 \mathrm{~nm}$ (violet), $540 \mathrm{~nm}$ (green) and $650 \mathrm{~nm}$ (red), assigned to ${ }^{4} \mathrm{G}_{11 / 2} \rightarrow{ }^{4} \mathrm{I}_{15 / 2},{ }^{2} \mathrm{H}_{9 / 2} \rightarrow{ }^{4} \mathrm{I}_{15 / 2},{ }^{2} \mathrm{H}_{11 / 2} /{ }^{4} \mathrm{~S}_{3 / 2} \rightarrow{ }^{4} \mathrm{I}_{15 / 2}$ and ${ }^{4} \mathrm{~F}_{9 / 2} \rightarrow$ ${ }^{4} \mathrm{I}_{15 / 2}$ transitions of $\mathrm{Er}^{3+}$, respectively. Quantitatively, highly doped $\mathrm{NaYF}_{4} @ \mathrm{NaYF}_{4}: \mathrm{Yb}_{0.8}, \mathrm{Er}_{0.06} @ \mathrm{NaYF}_{4}$ nanoparticles result in 39, 24, 6.4, and 21 fold brightness enhancements in ultraviolet, violet, green, and red, compared with the $\mathrm{NaYF}_{4} @ \mathrm{NaYF}_{4}: \mathrm{Yb}_{0.2}, \mathrm{Er}_{0.02} @ \mathrm{NaYF}_{4}$ nanocrystals under the excitation power of $0.25 \mathrm{~W} / \mathrm{cm}^{2}$. 

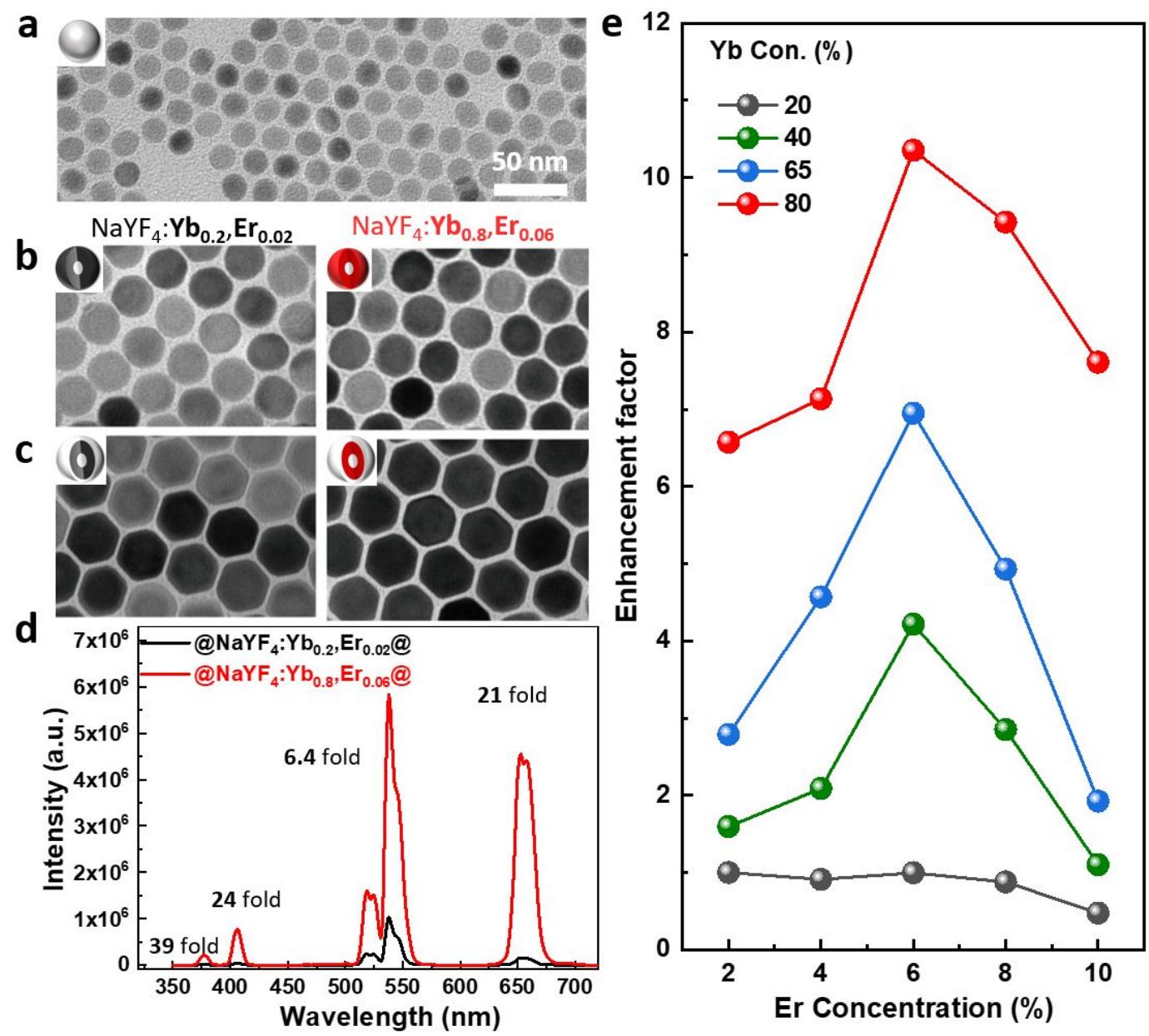

Figure 1. TEM images of $\mathrm{NaYF}_{4}$ core (a), NaYF $4 @ \mathrm{NaYF}_{4}: \mathrm{Yb}_{0.2}, \mathrm{Er}_{0.02}$ (b, left), NaYF${ }_{4} @ \mathrm{NaYF}_{4}: \mathrm{Yb}_{0.8}, \mathrm{Er}_{0.06}$ (b, right), NaYF ${ }_{4} @ N_{a Y F}: \mathrm{Yb}_{0.2}, \mathrm{Er}_{0.02} @ \mathrm{NaYF}_{4}$ (c, left), and NaYF $\mathrm{N}_{4} @ \mathrm{NaYF}_{4}: \mathrm{Yb}_{0.8}, \mathrm{Er}_{0.06} @ \mathrm{NaYF}_{4}$ (c, right), the scale bar is $50 \mathrm{~nm}$. (d) Luminescence spectra of $\mathrm{NaYF}_{4} @ \mathrm{NaYF}_{4}: \mathrm{Yb}_{0.8}, \mathrm{Er}_{0.06} @ \mathrm{NaYF}_{4}$ and $\mathrm{NaYF}_{4} @ \mathrm{NaYF}_{4}: \mathrm{Yb}_{0.2}, \mathrm{Er}_{0.02} @ \mathrm{NaYF}_{4}$ under the excitation power of $0.25 \mathrm{~W} / \mathrm{cm}^{2}$, (e) Integrated luminescence intensity enhancement of $\mathrm{NaYF}_{4} @ \mathrm{NaYF}_{4}: \mathrm{Yb}_{\mathrm{x}}, \mathrm{Er}_{\mathrm{y}} @ \mathrm{NaYF}_{4}$ samples compared with $\mathrm{NaYF}_{4} @ \mathrm{NaYF}_{4}: \mathrm{Yb}_{0.2}, \mathrm{Er}_{0.02} @ \mathrm{NaYF}_{4}$ under the excitation power of $0.25 \mathrm{~W} / \mathrm{cm}^{2}$.

We then systematically synthesize a series of 20 batches of UCNPs doped with different dopant combinations of sensitizer $(x)$ and activator $(y)$ and study their optical properties. We orthogonally apply four different $\mathrm{Yb}^{3+}$ concentrations $(x=20 \%, 40 \%, 65 \%$ and $80 \%)$ and five different $\mathrm{Er}^{3+}$ dopant concentrations $(y=2 \%, 4 \%, 6 \%, 8 \%$ and 10\%). All the nanoparticles have the same structure and size as confirmed by the TEM results (Fig. S2-5). As shown in Fig. 1e, the brightness of UCNPs increases with an increase of $\mathrm{Yb}^{3+}$ from $20 \%$ to $80 \%$ when fixing the doping concentration of $\mathrm{Er}^{3+}$, which is due to both the elevated photon harvest efficiency of the sensitizers and the reduced distance between donor and acceptor, as energy transfer rate is proportional to $d^{-6}$ in dipole-dipole interaction ( $d$ refers to the average donor-acceptor distance) ${ }^{28}$. The luminescence intensity first enhances with ascended 
$\mathrm{Er}^{3+}$ concentration from $2 \%$ to $6 \%$ and then declines with the $\mathrm{Er}^{3+}$ concentration above $6 \%$, showing a sign of the cross-relaxation induced energy loss. By fixing the $\mathrm{Er}^{3+}$ concentration at $6 \%$, we further increase the $\mathrm{Yb}^{3+}$ concentration to $94 \%$ (Fig. S6), and find that the luminescence intensity of $\mathrm{NaYF}_{4} @ \mathrm{NaYbF}_{4}: \mathrm{Er}_{0.06} @ \mathrm{NaYF}_{4}$ is lower than that of $\mathrm{NaYF}_{4} @ \mathrm{NaYF}_{4}: \mathrm{Yb}_{0.8}, \mathrm{Er}_{0.06} @ \mathrm{NaYF}_{4}(\mathbf{F i g} . \mathbf{S 7})$, which is consistent to the previous report. ${ }^{29}$ To further study the effect of $\mathrm{Yb}^{3+}$ concentration on the energy transfer process, we examine the time-resolved green emission of the samples with different $\mathrm{Yb}^{3+}$ concentrations. As shown in Fig. S8, the luminescence lifetime decreases from 252 to $99 \mu$ s as the $\mathrm{Yb}^{3+}$ concentration increases from $20 \%$ to $94 \%$, which indicates the back-energy-transfer process from $\mathrm{Er}^{3+}$ to $\mathrm{Yb}^{3+}$ in the highly doped samples. Therefore, the optimal $\mathrm{Yb}^{3+}$ concentration at $80 \%$ is to balance the effects of increasing absorption and reducing back-energy-transfer.

The luminescence enhancement of UCNPs can be strongly power-dependent. As shown in Fig. 2a, when the excitation power density increases from $0.25 \mathrm{~W} / \mathrm{cm}^{2}$ to $0.5 \mathrm{~W} / \mathrm{cm}^{2}$, the enhancement factors slightly decrease from $39,24,6.4$, and 21 folds to $23,13,3.7$, and 19 folds, at the ultraviolet, violet, green, and red emission bands, respectively. When the excitation power density decreases to $0.005 \mathrm{~W} / \mathrm{cm}^{2}$, the enhancement by the highly doped UCNPs is more obvious, e.g. 16 folds at the green band (Fig. 2b). To further understand the brightness enhancement of highly doped UCNPs, we systemically conduct power dependent luminescence measurements in the range of 0.005 to $0.5 \mathrm{~W} / \mathrm{cm}^{2}$, integrate the emissions from different bandwidth (Fig. S9) and further calculated the enhancement factors, as shown in Fig. 2c. The emission intensity ratio at $407 \mathrm{~nm}$ increases from 13.0 to 49.0 when the irradiance decreases from 0.5 to $0.062 \mathrm{~W} / \mathrm{cm}^{2}$. Similarly, luminescence enhancement at $379 \mathrm{~nm}$ increases around 3 times and achieves 75.3 at the irradiance of $0.081 \mathrm{~W} / \mathrm{cm}^{2}$. Also, the brightness enhancement factors of green and red luminescence $(540 \mathrm{~nm}$ and $650 \mathrm{~nm}$ ) increase from 3.7 and 19.0 to 15.2 and 38.0 , respectively, when the irradiance reduces from 0.5 to $0.016 \mathrm{~W} / \mathrm{cm}^{2}$. This trend is consistent with the increased probability of highly efficient energy absorption of the highly $\mathrm{Yb}^{3+}$-doped UCNPs at relatively low irradiance. 

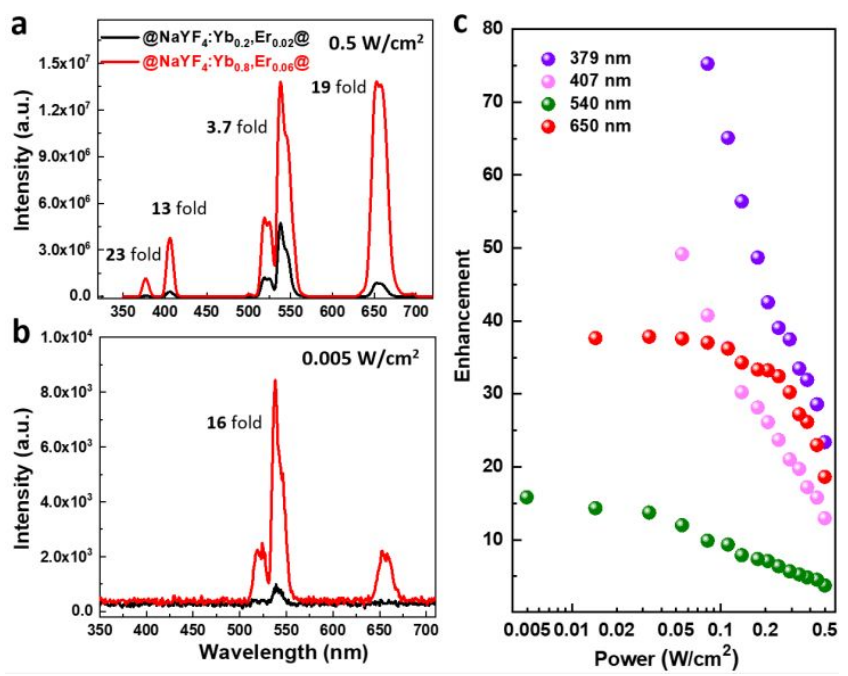

Figure 2. Luminescence spectra of

of $\quad \mathrm{NaYF}_{4} @ \mathrm{NaYF}_{4}: \mathrm{Yb}_{0.8}, \mathrm{Er}_{0.06} @ \mathrm{NaYF}_{4}$ and $\mathrm{NaYF}_{4} @ \mathrm{NaYF}_{4}: \mathrm{Yb}_{0.2}, \mathrm{Er}_{0.02} @ \mathrm{NaYF}_{4}$ under the irradiance of $0.5 \mathrm{~W} / \mathrm{cm}^{2}$ (a) and $0.005 \mathrm{~W} / \mathrm{cm}^{2}$ (b). (c) Comparison of power-dependent luminescence intensity enhancements between $\mathrm{NaYF}_{4} @ \mathrm{NaYF}_{4}: \mathrm{Yb}_{0.8}, \mathrm{Er}_{0.06} @ \mathrm{NaYF}_{4}$ and NaYF $\mathrm{N}_{4} @ \mathrm{NaYF}_{4}: \mathrm{Yb}_{0.2}, \mathrm{Er}_{0.02} @ \mathrm{NaYF}_{4}$ at UV (379 nm), violet (407 $\mathrm{nm})$, green $(540 \mathrm{~nm})$, and red $(650 \mathrm{~nm})$ bands, respectively.

We determine that the sensitizers' concentration dominates the power-dependent properties, as shown in Fig. 3. For the highly $\mathrm{Yb}^{3+}$-doped $\mathrm{NaYF}_{4} @ \mathrm{NaYF}_{4}: \mathrm{Yb}_{0.8}, \mathrm{Er}_{0.02} @ \mathrm{NaYF}_{4}$ nanoparticles, the brightness enhancement factors across all the emission bands significantly increase with the decrease of irradiance (Fig. 3a). For example, the enhancement factors of the UV emissions increase significantly from 17.1 to 52.5 . In contrast, the irradiance has negligible effect in the brightness enhancement factors for the highly Er ${ }^{3+}$-doped $\mathrm{NaYF}_{4} @ \mathrm{NaYF}_{4}: \mathrm{Yb}_{0.2}, \mathrm{Er}_{0.06} @ \mathrm{NaYF}_{4}$ nanoparticles (Fig. 3b). Similarly, with the optimal $\mathrm{Yb}^{3+}$ concentration of $80 \%$, the increase of $\mathrm{Er}^{3+}$ doping concentration from $2 \%$ to $6 \%$ only slightly increases the luminescence with the enhancement factor around 1.8 (Fig. 3c). Also, the enhancement factors do not change with the excitation power density. These results suggest the increased NIR photon sensitization becomes critical to increase the brightness of highly doped UCNPs under the mild and low irradiance conditions. 

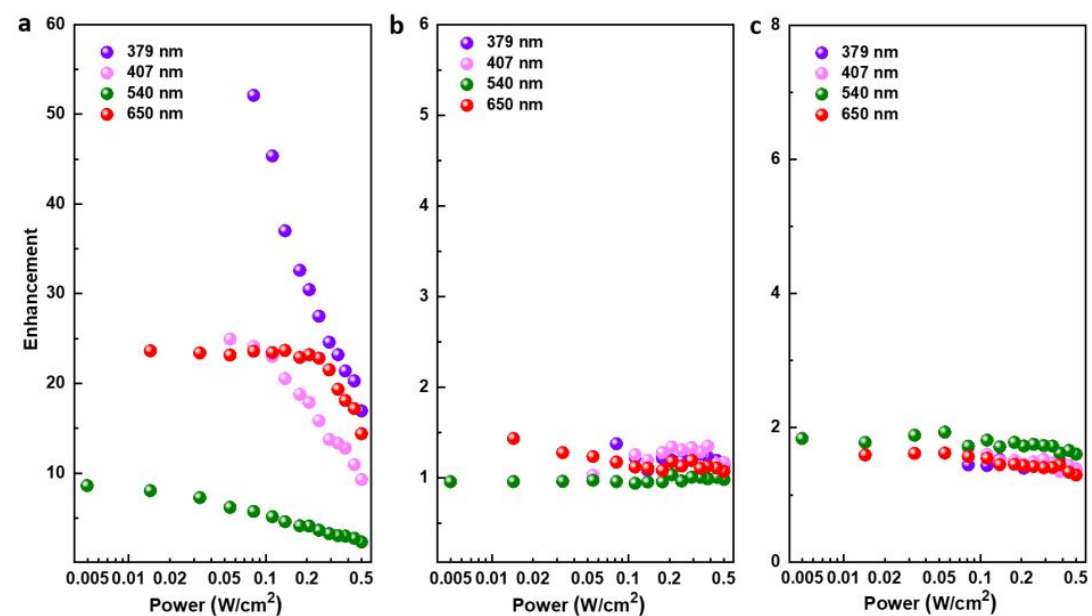

Figure 3. The power-dependent upconversion enhancement factors for $\mathrm{NaYF}_{4} @ \mathrm{NaYF}_{4}: \mathrm{Yb}_{0.8}, \mathrm{Er}_{0.02} @ \mathrm{NaYF}_{4}$ compared with $\mathrm{NaYF}_{4} @ \mathrm{NaYF}_{4}: \mathrm{Yb}_{0.2}, \mathrm{Er}_{0.02} @ \mathrm{NaYF}_{4}$ (a), $\mathrm{NaYF}_{4} @ \mathrm{NaYF}_{4}: \mathrm{Yb}_{0.2}, \mathrm{Er}_{0.06} @ \mathrm{NaYF}_{4}$ compared with $\mathrm{NaYF}_{4} @ \mathrm{NaYF}_{4}: \mathrm{Yb}_{0.2}, \mathrm{Er}_{0.02} @ \mathrm{NaYF}_{4}$ (b), and $\mathrm{NaYF}_{4} @ \mathrm{NaYF}_{4}: \mathrm{Yb}_{0.8}, \mathrm{Er}_{0.06} @ \mathrm{NaYF}_{4}$ compared with $\mathrm{NaYF}_{4} @ \mathrm{NaYF}_{4}: \mathrm{Yb}_{0.8}, \mathrm{Er}_{0.02} @ \mathrm{NaYF}_{4}$ (c) at different emission bands.

We then survey the broad range of demonstrated in vivo applications using the conventional $\mathrm{NaYF}_{4}: \mathrm{Yb}_{0.2}, \mathrm{Er}_{0.02} @ \mathrm{NaYF}_{4} \mathrm{UCNPs}$, as summarized in Table 1. We anticipate that the new formula of highly doped UCNPs will immediately offer at least one order of magnitude brightness enhancement or to achieve the same performance with a much reduced irradiance. For bioimaging, the red upconversion emissions are the preferable due to the less extinction through the tissues ${ }^{10,30}$, therefore the enhancement factor of 37 in red band using the $\mathrm{NaYF}_{4}: \mathrm{Yb}_{0.8}, \mathrm{Er}_{0.06} @ \mathrm{NaYF}_{4}$ will significantly improve the imaging sensitivity. Similarly, the improved photodynamic therapy treatment will be achieved by using the $\mathrm{NaYF}_{4}: \mathrm{Yb}_{0.8}, \mathrm{Er}_{0.06} @ \mathrm{NaYF}_{4}$, as the red emission from $\mathrm{Er}^{3+}$-doped UCNPs is commonly used to active photosensitizer (Zinc phthalocyanine) ${ }^{14,24}$. For NIR light-triggered drug release, the green emission of $\mathrm{NaYF}_{4}: \mathrm{Yb}_{0.2}, \mathrm{Er}_{0.02} @ \mathrm{NaYF}_{4}$ could be used to photolysis Roussin's black salt to generate NO under the excitation power of $5-30 \mathrm{~W} / \mathrm{cm}^{2}{ }^{3,31}$. Also, relatively high excitation power $\left(0.5-400 \mathrm{~W} / \mathrm{cm}^{2}\right)$ is needed for $\mathrm{NaYF}_{4}: \mathrm{Yb}_{0.2}, \mathrm{Er}_{0.02} @ \mathrm{NaYF}_{4}$ to generate the strong green light for optogenetics applications ${ }^{13,32}$. With the usage of $\mathrm{NaYF}_{4}: \mathrm{Yb}_{0.8}, \mathrm{Er}_{0.06} @ \mathrm{NaYF}_{4}$, the excitation power could be significantly reduced for safety in vivo drug delivery and optogenetics applications. Recently, Ma et al. developed ocular injectable photoreceptor-binding UCNPs to extend the mammalian visual spectrum into the NIR range under the excitation power of $0.0016 \mathrm{~W} / \mathrm{cm}^{2}{ }^{17}$. We anticipate the new doping formula will improve the green emission for around 15 times and significantly improve the 
sensitivity to the NIR light.

Table 1. A summary of the anticipated improvements for the highly doped UCNPs in bio applications

\begin{tabular}{|c|c|c|c|c|c|}
\hline $\begin{array}{l}\text { Recommended } \\
\text { applications }\end{array}$ & $\begin{array}{l}\text { Upconversion } \\
\text { nanoparticles }\end{array}$ & $\begin{array}{l}\text { Desirable } \\
\text { emission band }\end{array}$ & $\begin{array}{l}\text { Irradiance } \\
\text { range }\end{array}$ & Ref. & $\begin{array}{l}\text { Anticipated improvement if using the new } \\
\text { doping formula }\end{array}$ \\
\hline $\begin{array}{l}\text { In vivo bio- } \\
\text { imaging }\end{array}$ & $\mathrm{NaYF}_{4}: \mathrm{Yb}_{0.2}, \mathrm{Er}_{0.02}$ & $\begin{array}{l}\operatorname{Red}(600 \sim 700 \\
\mathrm{nm})\end{array}$ & $0.12 \mathrm{~W} / \mathrm{cm}^{2}$ & 30 & 38 times luminescence enhancement \\
\hline $\begin{array}{l}\text { Photodynamic } \\
\text { therapy }\end{array}$ & $\mathrm{NaYF}_{4}: \mathrm{Yb}_{0.2}, \mathrm{Er}_{0.02}$ & $\operatorname{Red}(\sim 650 \mathrm{~nm})$ & $\begin{array}{l}0.39-0.415 \\
\mathrm{~W} / \mathrm{cm}^{2}\end{array}$ & 14,24 & $\begin{array}{l}26 \text { times luminescence enhancement or reduce } \\
\text { the irradiance to }<0.1 \mathrm{~W} / \mathrm{cm}^{2}\end{array}$ \\
\hline $\begin{array}{l}\text { Drug release } \\
\text { and delivery }\end{array}$ & $\mathrm{NaYF}_{4}: \mathrm{Yb}_{0.25}, \mathrm{Er}_{0.02}$ & $\begin{array}{l}\text { Green }(510 \sim \\
560 \mathrm{~nm})\end{array}$ & $\begin{array}{l}0.5-400 \\
\mathrm{~W} / \mathrm{cm}^{2}\end{array}$ & 31 & $\begin{array}{l}\sim 15 \text { times luminescence enhancement or } \\
\text { reduce the irradiance to }<0.5 \mathrm{~W} / \mathrm{cm}^{2}\end{array}$ \\
\hline Optogenetics & $\begin{array}{l}\mathrm{NaYF}_{4}: \mathrm{Yb}_{0.2}, \mathrm{Er}_{0.02} \\
@ \mathrm{NaYF}_{4}\end{array}$ & $\begin{array}{l}\text { Green }(510 \sim \\
560 \mathrm{~nm})\end{array}$ & $\begin{array}{l}0.44-140 \\
\mathrm{~W} / \mathrm{cm}^{2}\end{array}$ & 13,32 & $\begin{array}{l}\sim 10 \text { times luminescence enhancement or } \\
\text { reduce the irradiance to }<0.8 \mathrm{~W} / \mathrm{cm}^{2}\end{array}$ \\
\hline $\begin{array}{l}\text { Night vision } \\
\text { enhancement }\end{array}$ & $\begin{array}{l}\mathrm{NaYF}_{4}: \mathrm{Yb}_{0.2}, \mathrm{Er}_{0.02} \\
@ \mathrm{NaYF}_{4}\end{array}$ & $\begin{array}{l}\text { Green }(\sim 550 \\
\mathrm{nm})\end{array}$ & $\begin{array}{l}0.0016 \\
\mathrm{~W} / \mathrm{cm}^{2}\end{array}$ & 17 & $\sim 15$ times luminescence enhancement \\
\hline
\end{tabular}

We further validate the advantage of the highly doped UCNPs for in vivo tumor imaging. In this experiment, as ideal nanoparticles with the smaller size are preferred due to higher efficiency in cargos delivery, and their improved body clearance and biocompatibility ${ }^{33}$, we simplify our design into $\mathrm{NaYF}_{4}: \mathrm{Yb}_{0.8}, \mathrm{Er}_{0.06} @ \mathrm{NaYF}_{4}$ so that smaller sized highly doped UCNPs can be synthesized. The $\mathrm{NaYF}_{4}: \mathrm{Yb}_{0.8}, \mathrm{Er}_{0.06}$ active cores display a narrow size distribution with an average diameter of $8.6 \mathrm{~nm}$, and the final size of $\mathrm{NaYF}_{4}: \mathrm{Yb}_{0.8}, \mathrm{Er}_{0.06} @ \mathrm{NaYF}_{4}$ is measured to be $11.9 \mathrm{~nm}$ (Fig. S10a-b), smaller than the size of dye-labelled IgG antibody ${ }^{34}$. It should be noted that the formula of $\mathrm{NaYF}_{4}: \mathrm{Yb}_{0.8}, \mathrm{Er}_{0.06} @ \mathrm{NaYF}_{4} \mathrm{UCNPs}$ displays the enhanced emission compared with that with low doping concentrations (Fig. S10c), suggesting that the optimal concentrations of $\mathrm{Yb}^{3+}$ and $\mathrm{Er}^{3+}$ ions are independent on the size of the nanoparticles.

To demonstrate the improved brightness and tissue penetration ability of the $12 \mathrm{~nm}$ highly doped UCNPs, we first test them underneath the pork tissue (Fig. S11). As shown in Fig. 4a-b, using an irradiance of $0.5 \mathrm{~W} / \mathrm{cm}^{2}$, the strong $660 \mathrm{~nm}$ band upconversion image of $\mathrm{NaYF}_{4}: \mathrm{Yb}_{0.8}, \mathrm{Er}_{0.06} @ \mathrm{NaYF}_{4}$ can be detected at a tissue depth of $4.0 \mathrm{~mm}$, while the signal of conventional 
$\mathrm{NaYF}_{4}: \mathrm{Yb}_{0.2}, \mathrm{Er}_{0.02} @ \mathrm{NaYF}_{4} \mathrm{UCNPs}$ can only penetrate $1.0 \mathrm{~mm}$. Quantitatively, the signal to noise ratio (SNR) of $\mathrm{NaYF}_{4}: \mathrm{Yb}_{0.8}, \mathrm{Er}_{0.06} @ \mathrm{NaYF}_{4}$ covered by $1 \mathrm{~mm}$ pork tissue is around 20, which is 5 times higher than the SNR of $\mathrm{NaYF}_{4}: \mathrm{Yb}_{0.2}, \mathrm{Er}_{0.02} @ \mathrm{NaYF}_{4} \mathrm{UCNPs}(\mathbf{F i g} .4 \mathbf{c})$. The penetration ability of green luminescent signals from both $\mathrm{NaYF}_{4}: \mathrm{Yb}_{0.8}, \mathrm{Er}_{0.06} @ \mathrm{NaYF}_{4}$ and $\mathrm{NaYF}_{4}: \mathrm{Yb}_{0.2}, \mathrm{Er}_{0.02} @ \mathrm{NaYF}_{4}$ is relative weak, as the green SNR of $\mathrm{NaYF}_{4}: \mathrm{Yb}_{0.8}, \mathrm{Er}_{0.06} @ \mathrm{NaYF}_{4}$ covered by $1 \mathrm{~mm}$ pork tissue is 6.1 while the $\mathrm{SNR}$ of $\mathrm{NaYF}_{4}: \mathrm{Yb}_{0.2}, \mathrm{Er}_{0.02} @ \mathrm{NaYF}_{4} \mathrm{UCNPs}$ is only 1.5 (Figure S12).
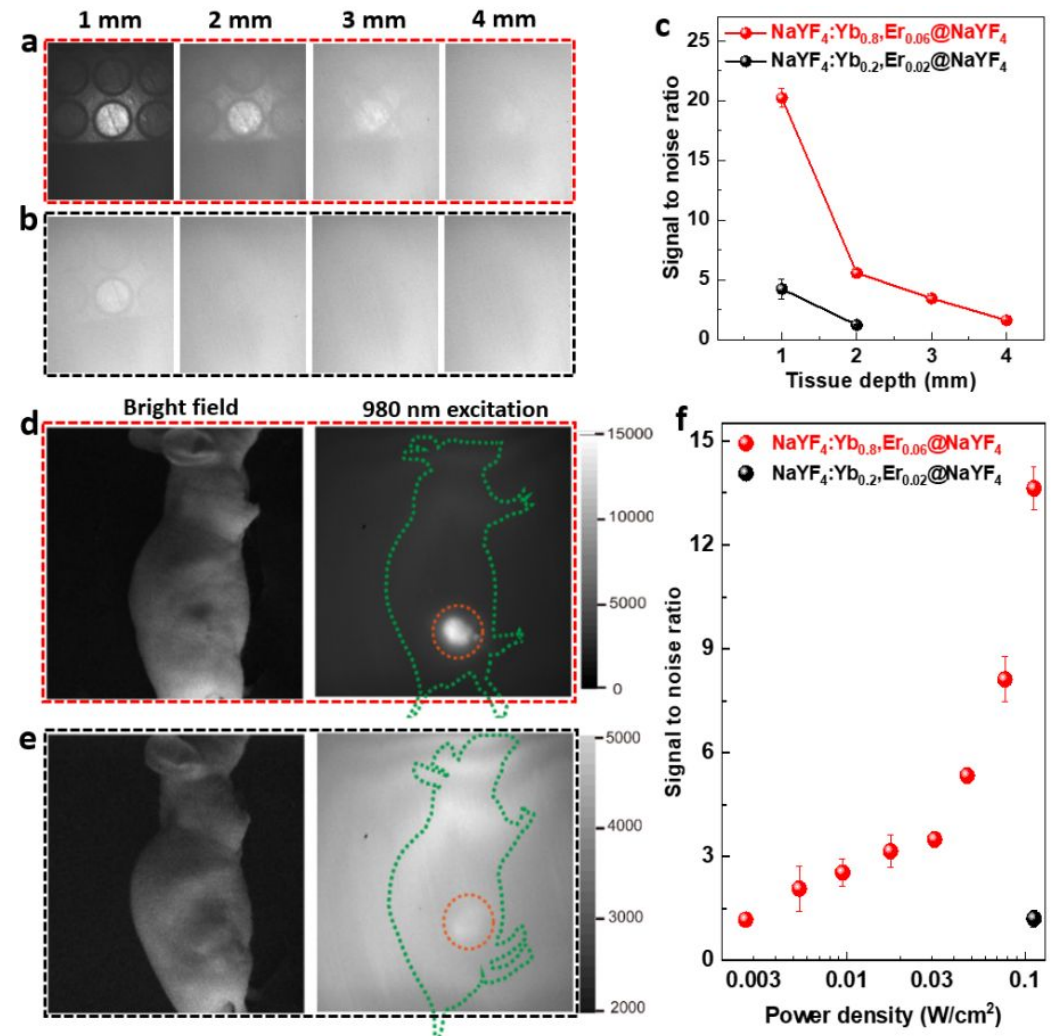

Figure 4. Luminescence imaging of $\mathrm{NaYF}_{4}: \mathrm{Yb}_{0.8}, \mathrm{Er}_{0.06} @ \mathrm{NaYF}_{4}(\mathbf{a})$ and $\mathrm{NaYF}_{4}: \mathrm{Yb}_{0.2}, \mathrm{Er}_{0.02} @ \mathrm{NaYF}_{4}(\mathbf{b})$ at $660 \pm 13 \mathrm{~nm}$ under different thickness of pork tissue. (c) Quantitative analysis of luminescent signal to noise ratio. In vivo tumor imaging of mice injected with $\mathrm{NaYF}_{4}: \mathrm{Yb}_{0.8}, \mathrm{Er}_{0.06} @ \mathrm{NaYF}_{4}$ (d) and $\mathrm{NaYF}_{4}: \mathrm{Yb}_{0.2}, \mathrm{Er}_{0.02} @ \mathrm{NaYF}_{4}$ (e) with the $980 \mathrm{~nm}$ laser intensity of $0.112 \mathrm{~W} / \mathrm{cm}^{2}$. (f) The powerdependent signal to noise ratio of the tumor site injected with the upconversion contrast agents.

To demonstrate $\mathrm{NaYF}_{4}: \mathrm{Yb}_{0.8}, \mathrm{Er}_{0.06} @ \mathrm{NaYF}_{4} \mathrm{UCNPs}$ as a more efficient contrast agent for bio imaging, we perform an in vivo tumor imaging experiment in the mouse model. As shown in Fig. 4 d-e, the tumor site shows an obvious luminescence signals after the administration of $\mathrm{NaYF}_{4}: \mathrm{Yb}_{0.8}, \mathrm{Er}_{0.06} @ \mathrm{NaYF}_{4}$ under the excitation power density of $0.112 \mathrm{~W} / \mathrm{cm}^{2}$, while the tumor site injected with $\mathrm{NaYF}_{4}: \mathrm{Yb}_{0.2}, \mathrm{Er}_{0.02} @ \mathrm{NaYF}_{4}$ only shows a quite weak signal. Further reducing the excitation power, the luminescence signals of both samples becomes weaker (Fig. S13). The minimum 


\section{Associated Content}

Supporting Information

The Supporting Information is available on the ACS Publications website including:

Detailed experiment sections, UCNPs synthesis, TEM images and size distribution histograms, luminescent spectra, integrated luminescent signals, In vitro and in vivo luminescence images

\section{Acknowledgement}

We thank S. Lindsay and C. Shen in Microscope Unit at Macquarie University for TEM characterization. This project is financially supported by Australia-China Joint Research Centre for Point-of-Care Testing (ACSRF65827, SQ2017YFGH001190), Science and Technology Innovation Commission of Shenzhen (KQTD20170810110913065), National Natural Science Foundation of 
China (NSFC, 61729501, 51720105015). D. L. and Y. L acknowledge the financial support from China Scholarship Council scholarships (Du Li: No. 201506630038; Yongtao Liu: No. 201607950010.)

\section{References}

(1) Zhou, B.; Shi, B.; Jin, D.; Liu, X., Controlling upconversion nanocrystals for emerging applications. Nat. Nanotechnol. 2015, 10, 924.

(2) Dong, H.; Du, S.-R.; Zheng, X.-Y.; Lyu, G.-M.; Sun, L.-D.; Li, L.-D.; Zhang, P.-Z.; Zhang, C.; Yan, C.-H., Lanthanide Nanoparticles: From Design toward Bioimaging and Therapy. Chem. Rev. 2015, 115 (19), 10725-10815.

(3) Yang, D.; Ma, P. a.; Hou, Z.; Cheng, Z.; Li, C.; Lin, J., Current advances in lanthanide ion (Ln3+)-based upconversion nanomaterials for drug delivery. Chem. Soc. Rev. 2015, 44 (6), 1416-1448.

(4) Deng, R.; Qin, F.; Chen, R.; Huang, W.; Hong, M.; Liu, X., Temporal full-colour tuning through non-steady-state upconversion. Nat. Nanotechnol. 2015, 10 (3), 237-242.

(5) Zhou, J.; Wen, S.; Liao, J.; Clarke, C.; Tawfik, S. A.; Ren, W.; Mi, C.; Wang, F.; Jin, D., Activation of the surface dark-layer to enhance upconversion in a thermal field. Nat. Photon. 2018, 12 (3), 154-158.

(6) Zhang, Q.; Yang, F.; Xu, Z.; Chaker, M.; Ma, D., Are lanthanide-doped upconversion materials good candidates for photocatalysis? Nanoscale Horiz. 2019.

(7) Yang, W.; Li, X.; Chi, D.; Zhang, H.; Liu, X., Lanthanide-doped upconversion materials: emerging applications for photovoltaics and photocatalysis. Nanotechnology 2014, 25 (48), 482001.

(8) Zhang, H.; Fan, Y.; Pei, P.; Sun, C.; Lu, L.; Zhang, F., Tm3+-Sensitized NIR-II Fluorescent Nanocrystals for In Vivo Information Storage and Decoding. Angew. Chem., Int. Ed. 2019, 58 (30), 10153-10157.

(9) Liu, Q.; Sun, Y.; Yang, T.; Feng, W.; Li, C.; Li, F., Sub-10 nm Hexagonal LanthanideDoped NaLuF4 Upconversion Nanocrystals for Sensitive Bioimaging in Vivo. J. Am. Chem. Soc. 2011, 133 (43), 17122-17125.

(10)Zhou, J.; Liu, Z.; Li, F., Upconversion nanophosphors for small-animal imaging. Chem. Soc. Rev. 2012, 41 (3), 1323-1349.

(11)Fan, Y.; Wang, P.; Lu, Y.; Wang, R.; Zhou, L.; Zheng, X.; Li, X.; Piper, J. A.; Zhang, F., Lifetime-engineered NIR-II nanoparticles unlock multiplexed in vivo imaging. Nat. Nanotechnol. 2018, 13 (10), 941-946.

(12)Wang, S.; Liu, L.; Fan, Y.; El-Toni, A. M.; Alhoshan, M. S.; li, D.; Zhang, F., In Vivo High-resolution Ratiometric Fluorescence Imaging of Inflammation Using NIR-II Nanoprobes with $1550 \mathrm{~nm}$ Emission. Nano Lett. 2019, 19 (4), 2418-2427.

(13)Chen, S.; Weitemier, A. Z.; Zeng, X.; He, L.; Wang, X.; Tao, Y.; Huang, A. J. Y.; Hashimotodani, Y.; Kano, M.; Iwasaki, H.; Parajuli, L. K.; Okabe, S.; Teh, D. B. L.; All, A. H.; Tsutsui-Kimura, I.; Tanaka, K. F.; Liu, X.; McHugh, T. J., Near-infrared deep brain stimulation via upconversion nanoparticle-mediated optogenetics. Science 2018, 359 (6376), 679-684. (14)Idris, N. M.; Gnanasammandhan, M. K.; Zhang, J.; Ho, P. C.; Mahendran, R.; Zhang, Y., In vivo photodynamic therapy using upconversion nanoparticles as remote-controlled nanotransducers. Nat. Med. 2012, 18 (10), 1580-1585. 
(15)Nam, S. H.; $\quad$ Bae, Y. M.; $\quad$ Park, Y. I.; Kim, J. H.; Kim, H. M.; Choi, J. S.; Lee, K. T.; Hyeon, T.; Suh, Y. D., Long-Term Real-Time Tracking of Lanthanide Ion Doped Upconverting Nanoparticles in Living Cells. Angew. Chem., Int. Ed. 2011, 50 (27), 6093-6097.

(16)Ximendes, E. C.; Santos, W. Q.; Rocha, U.; Kagola, U. K.; Sanz-Rodríguez, F.; Fernández, N.; Gouveia-Neto, A. d. S.; Bravo, D.; Domingo, A. M.; del Rosal, B.; Brites, C. D. S.; Carlos, L. D.; Jaque, D.; Jacinto, C., Unveiling in Vivo Subcutaneous Thermal Dynamics by Infrared Luminescent Nanothermometers. Nano Lett. 2016, 16 (3), 1695-1703.

(17)Ma, Y.; Bao, J.; Zhang, Y.; Li, Z.; Zhou, X.; Wan, C.; Huang, L.; Zhao, Y.; Han, G.; Xue, T., Mammalian Near-Infrared Image Vision through Injectable and Self-Powered Retinal Nanoantennae. Cell 2019, 177 (2), 243-255.e15.

(18)Wang, F.; Liu, X., Upconversion Multicolor Fine-Tuning: Visible to Near-Infrared Emission from Lanthanide-Doped NaYF4 Nanoparticles. J. Am. Chem. Soc. 2008, 130 (17), 5642-5643.

(19)Krämer, K. W.; Biner, D.; Frei, G.; Güdel, H. U.; Hehlen, M. P.; Lüthi, S. R., Hexagonal Sodium Yttrium Fluoride Based Green and Blue Emitting Upconversion Phosphors. Chem. Mater. 2004, 16 (7), 1244-1251.

(20)Zhao, J.; Jin, D.; Schartner, E. P.; Lu, Y.; Liu, Y.; Zvyagin, A. V.; Zhang, L.; Dawes, J. M.; Xi, P.; Piper, J. A.; Goldys, E. M.; Monro, T. M., Single-nanocrystal sensitivity achieved by enhanced upconversion luminescence. Nat. Nanotechnol. 2013, 8, 729.

(21)Tian, B.; Fernandez-Bravo, A.; Najafiaghdam, H.; Torquato, N. A.; Altoe, M. V. P.; Teitelboim, A.; Tajon, C. A.; Tian, Y.; Borys, N. J.; Barnard, E. S.; Anwar, M.; Chan, E. M.; Schuck, P. J.; Cohen, B. E., Low irradiance multiphoton imaging with alloyed lanthanide nanocrystals. Nat. Commun. 2018, 9 (1), 3082.

(22)Liu, Q.; Zhang, Y.; Peng, C. S.; Yang, T.; Joubert, L.-M.; Chu, S., Single upconversion nanoparticle imaging at sub-10 W cm-2 irradiance. Nat. Photon. 2018, 12 (9), 548-553.

(23)Ma, C.; Xu, X.; Wang, F.; Zhou, Z.; Liu, D.; Zhao, J.; Guan, M.; Lang, C. I.; Jin, D., Optimal Sensitizer Concentration in Single Upconversion Nanocrystals. Nano Lett. 2017, 17 (5), 2858 2864.

(24)Xia, L.; Kong, X.; Liu, X.; Tu, L.; Zhang, Y.; Chang, Y.; Liu, K.; Shen, D.; Zhao, H.; Zhang, H., An upconversion nanoparticle - Zinc phthalocyanine based nanophotosensitizer for photodynamic therapy. Biomaterials 2014, 35 (13), 4146-4156.

(25)Wang, F.; Wang, J.; Liu, X., Direct Evidence of a Surface Quenching Effect on Size-Dependent Luminescence of Upconversion Nanoparticles. Angew. Chem., Int. Ed. 2010, 49 (41), 7456-7460.

(26)Gargas, D. J.; Chan, E. M.; Ostrowski, A. D.; Aloni, S.; Altoe, M. V. P.; Barnard, E. S.; Sanii, B.; Urban, J. J.; $\quad$ Milliron, D. J.; Cohen, B. E.; Schuck, P. J., Engineering bright sub-10-nm upconverting nanocrystals for single-molecule imaging. Nat. Nanotechnol. 2014, 9, 300.

(27)Li, X.; Shen, D.; Yang, J.; Yao, C.; Che, R.; Zhang, F.; Zhao, D., Successive Layer-byLayer Strategy for Multi-Shell Epitaxial Growth: Shell Thickness and Doping Position Dependence in Upconverting Optical Properties. Chem. Mater. 2013, 25 (1), 106-112.

(28)Wen, S.; Zhou, J.; Zheng, K.; Bednarkiewicz, A.; Liu, X.; Jin, D., Advances in highly doped upconversion nanoparticles. Nat. Commun. 2018, 9 (1), 2415.

(29)Punjabi, A.; Wu, X.; Tokatli-Apollon, A.; El-Rifai, M.; Lee, H.; Zhang, Y.; Wang, C.; Liu, Z.; Chan, E. M.; Duan, C.; Han, G., Amplifying the Red-Emission of Upconverting 
Nanoparticles for Biocompatible Clinically Used Prodrug-Induced Photodynamic Therapy. ACS Nano 2014, 8 (10), 10621-10630.

(30)Xiong, L.-Q.; Chen, Z.-G.; Yu, M.-X.; Li, F.-Y.; Liu, C.; Huang, C.-H., Synthesis, characterization, and in vivo targeted imaging of amine-functionalized rare-earth up-converting nanophosphors. Biomaterials 2009, 30 (29), 5592-5600.

(31)Garcia, J. V.; Yang, J.; Shen, D.; Yao, C.; Li, X.; Wang, R.; Stucky, G. D.; Zhao, D.; Ford, P. C.; Zhang, F., NIR-Triggered Release of Caged Nitric Oxide using Upconverting Nanostructured Materials. Small 2012, 8 (24), 3800-3805.

(32)Wang, Y.; Lin, X.; Chen, X.; Chen, X.; Xu, Z.; Zhang, W.; Liao, Q.; Duan, X.; Wang, X.; Liu, M.; Wang, F.; He, J.; Shi, P., Tetherless near-infrared control of brain activity in behaving animals using fully implantable upconversion microdevices. Biomaterials 2017, 142, 136148 .

(33)Li, C.; Xu, L.; Liu, Z.; Li, Z.; Quan, Z.; Al Kheraif, A. A.; Lin, J., Current progress in the controlled synthesis and biomedical applications of ultrasmall $(<10 \mathrm{~nm})$ NaREF4 nanoparticles. Dalton Trans. 2018, 47 (26), 8538-8556.

(34)Jin, D.; Xi, P.; Wang, B.; Zhang, L.; Enderlein, J.; van Oijen, A. M., Nanoparticles for super-resolution microscopy and single-molecule tracking. Nat. Methods 2018, 15 (6), 415-423. 
TOC
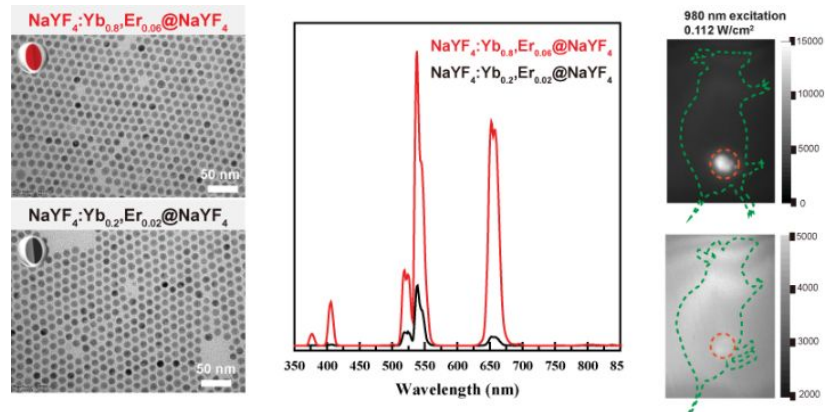

15 